\title{
Peningkatan Skill Berwirausaha UMKM Tunjung Segara Melalui Penerapan Model Paticipatory Rural Appraisal (PRA)
}

\author{
Ni Ketut Sari Adnyani ${ }^{1}$, Elly Herliyani ${ }^{2}$, I Gusti Ayu Purnamawati ${ }^{3}$ \\ 1,2,3 Universitas Pendidikan Ganesha, Singaraja - Indonesia
}

\section{A R T I C L EI N F 0}

\section{Article history:}

Received September, 22 2021

Received in revised form November, 152021

Accepted November 2021 Available online December, 252021

\section{Kata Kunci:}

Berwirausaha, model

paticipatory rural appraisal (PRA), skills.

Keywords:

Entrepreneurship, the paticipatory rural appraisal (PRA) model, skills.

\section{A B S T R A K}

Tujuan penelitian ini adalah untuk meningkatkan skills berwirausaha dalam pengembangan UMKM Tunjung Segara penerapan model Paticipatory Rural Appraisal (PRA) berbasis kinerja. Jenis penelitian adalah penelitian Tindakan (action research). Subjek penelitian adalah para pekerja di UMKM Tunjung Segara yang berjumlah 20 orang. Data kuantitatif dikumpulkan berupa angket dan dianalisis secara deskriptif kuantitatif._Hasil penelitian menunjukkan bahwa pengolahan data uji regresi linier sederhana nilai konstanta dan koefisien regresi menunjukkan bahwa variabel skill kewirausahaan $(\mathrm{X})$ berpengaruh secara positif terhadap pengembangan UMKM (Y) dengan penerapan model Paticipatory Rural Appraisal (PRA) jika variabel skill kewirausahaan ditingkatkan sebesar satu satuan, maka kinerja usaha akan meningkat sebesar 66.43. Hasil Uji Hipotesis (Uji T) Variabel skill kewirausahaan (X) memiliki nilai t hitung lebih besar dari nilai t tabel karena nilai t hitung $(5,387)>t$ tabel $(0,444)$ dan tingkat signifikansi $, 000<0,05$, maka Ho ditolak dan Ha diterima. Hasil Uji t Pengaruh Skill Pekerja terhadap Pengembangan UMKM, maka koefisien Determinasi (R2) Koefisien determinasi (R2) digunakan untuk melihat seberapa besar kontribusi variabel bebas (X) yaitu skill kewirausahan terhadap variabel terikat (Y) yaitu pengembangan UMKM. Berdasarkan hasil analisis koefisien determinasi didapatkan hasil bahwa besarnya pengaruh variabel skill kewirausahaan (X) terhadap variabel pengembangan UMKM (Y) adalah sebesar 73,9\%. Sedangkan sisanya sebesar 36,3\% dipengaruhi oleh faktor lain seperti SDM, motivasi, dan pendampingan. Kepada UMKM di Indonesia, model Paticipatory Rural Appraisal (PRA) berbasis kinerja dalam menunjang peningkatan skill berwirausaha sehingga semakin banyak UMKM yang dapat mengembangkan skill kewirausahaannya.

\section{A B S T R A C T}

The purpose of this study is to improve entrepreneurship skills in the development of Tunjung Segara MSMEs by applying the performance-based Paticipatory Rural Appraisal (PRA) model. The type of research is action research (action research). The research subjects were workers at Tunjung Segara SMEs, totaling 20 people. Quantitative data were collected in the form of a questionnaire and analyzed descriptively quantitatively. The results showed that the data processing of simple linear regression test constant values and regression coefficients showed that the entrepreneurial skill variable $(\mathrm{X})$ had a positive effect on the development of MSMEs (Y) with the application of the Paticipatory Rural Appraisal (PRA) model if the entrepreneurial skill variable was increased by one unit, then business performance will increase by 66.43. Hypothesis Test Results (T test) The entrepreneurial skill variable (X) has a t-count value greater than the t-table value because the $t$-count value (5.387) $>t$ table $(0.444)$ and the significance level is $.000<0.05$, then Ho is rejected and Ha accepted. The results of the t-test of the influence of worker skills on the development of SMEs, the coefficient of determination (R2) The coefficient of determination (R2) is used to see how much contribution the independent variable $(\mathrm{X})$ is entrepreneurship skills to the dependent variable $(\mathrm{Y})$, namely the development of SMEs. Based on the results of the analysis of the coefficient of determination, it was found that the magnitude of the influence of the entrepreneurial skill variable $(\mathrm{X})$ on the MSME development variable (Y) was $73.9 \%$. While the remaining $36.3 \%$ is influenced by other factors such as human resources, motivation, and mentoring. For MSMEs in Indonesia, the performance-based Paticipatory Rural Appraisal (PRA) model supports the improvement of entrepreneurship skills so that more MSMEs can develop their entrepreneurial skills. 


\section{Pendahuluan}

Pengembangan pembangunan ekonomi yang berbasis partisipasi masyarakat luas sebagai pelaku usaha merupakan komitmen pemerintah dalam pembangunan ekonomi (Heliantina, 2017). Pertumbuhan ekonomi di Indonesia didorong oleh beberapa sektor, salah satu sektor yang mempunyai peran sangat strategis adalah sektor Usaha Mikro, Kecil Dan Menengah atau UMKM sebagai salah satu fondasi perekonomian nasional (Sri \& Ahmad, 2017 : 182). Keberadaan UMKM tidak dapat dihapuskan ataupun dihindarkan dari masyarakat bangsa saat ini. Karena keberadaannya sangat bermanfaat dalam hal pendistribusian pendapatan masyarakat. Selain itu juga mampu menciptakan kreatifitas yang sejalan dengan usaha untuk mempertahankan dan mengembangkan unsur-unsur tradisi dan kebudayaan masyarakat setempat. Pada sisi lain, UMKM mampu menyerap tenaga kerja dalam skala yang besar mengingat jumlah penduduk Indonesia yang besar sehingga hal ini dapat mengurangi tingkat pengangguran. Dari sinilah terlihat bahwa keberadaan UMKM yang bersifat padat karya, menggunakan teknologi yang sederhana dan mudah dipahami mampu menjadi sebuah wadah bagi masyarakat untuk bekerja (Anggraeni, $2013: 1286$ ).

Program pengembangan Usaha Mikro, Kecil, dan Menengah (UMKM) sebagai salah satu instrument untuk menaikkan daya beli masyarakat, pada akhirnya akan menjadi katup pengaman dari situasi krisis sebagai dampak pandemic covid 19. Pengembangan UMKM menjadi sangat strategis dalam menggerakkan perekonomian nasional, mengingat kegiatan usahanya mencakup hampir semua lapangan usaha sehingga kontribusi UMKM menjadi sangat besar bagi peningkatan pendapatan bagi kelompok masyarakat berpendapatan rendah. UMKM selama ini terbukti dapat diandalkan sebagai bisnis pengaman di masa krisis, melalui mekanisme penciptaan lapangan kerja dan memungkinkan dihimpunnya penerimaan negara berupa pajak. Peran dan fungsi strategis ini, sesungguhnya dapat ditingkatkan dengan memerankan UMKM sebagai salah satu pelaku usaha komplementer bagi pengembangan perekonomian nasional (Christiana, Pradhanawati, \& Hidayat, 2014 : 387). UMKM yang maju tidak lepas dari usaha yang gigih dari pelakunya dengan skillnya sehingga menghasilkan sesuatu yang baru dan mempunyai daya saing.

Salah satu bagian penting dari pengembangan UMKM adalah skill, dan pada umumnya tidak ada yang terbebas darinya. Skill adalah bagian penunjang eksisnya kehidupan seseorang termasuk pekerja di UMKM. Setiap orang mempunyai kreativitas, dan yang membedakan adalah tingkatkreativitas antara orang satu dengan yang lainnya (Sutipyo, 2014 : 207). Skill adalah kemampuan dalam memikirkan sesuatu dengan cara baru yang tidak biasa dan menampilkan cara pemecahan masalah yang unik. Skill dan kecerdasan bukan hal yang sama. Sternberg memperkenalkan skill dalam teori mengenai kecerdasan, mengatakan bahwa banyak orang-orang yang kecerdasannya tinggi yang menghasilkan karya karya besar tetapi tidak selalu karya-karya baru (Hendrawan, Kuswantoro \& Sucahyawati, 2019 : 25-26). Peningkatan skill UMKM dalam mengelola bisnis sangatlah penting dilakukan mengingat keterampilan berbisnis bisa didapatkan melalui magang kerja serta pelatihan-pelatihan keterampilan membuat produk lebih disukai konsumen, selain itu skill berwirausaha UMKM juga dapat dilakukan dengan simulasi atau studi kasuskasus bisnis yang dapat meningkatkan skill UMKM dalam berwirausaha. Skill yang harus dimiliki oleh UMKM yaitu skill dalam membuat desain produk, skill melakukan promosi penjualan serta mengelola keuangan perusahaan sehingga perusahaan yang dijalankan dapat berjalan dengan baik dan mampu bersaing dengan perusahaan sejenis.

Kecerdasan saja tidak akan menjamin seseorang untuk menjadi pribadi yang kreatif, sukses dan bahagia, bila orang itu hanya puas dengan kecerdasannya tanpa berpikir bagaimana meningkatkan dan mengembangkan potensi-potensi bakatnya secara maksimal. Hal yang terpenting dalam dunia yang terus berubah dan sangat kompetitif ini adalah kemampuan untuk kreatif terhadap tantangan baru, bersama dengan suatu kemampuan mengantisipasi perkembangan dan inovatif.

UMKM diketahui cukup banyak menghasilkan produk-produk hasil kreatif. Hal ini sering terlihat di berbagai daerah di Indonesia berbagai produk yang sangat beragam diciptakan dan terdapat di pasaran. Tidak sedikit dari para pemilik UMKM tersebut menjadi seorang wirausaha yang maju dan berkembang. Melihat produk yang dihasilkannya, terdapat beberapa jenis produk di usaha kecil tersebut seperti produk makanan olahan, tekstil/fashion, barang kayu dan hasil hutan, kertas dan barang cetakan, barang dari logam serta lainnya. Tidak sedikit pula produk yang dihasilkan dibutuhkan sebagai produk antara atau sebagai bahan baku untuk proses produksi di industri menengah dan besar, termasuk yang dikonsumsi oleh konsumen luar negeri disamping konsumen dalam negeri sendiri. Ini menunjukkan bahwa produk hasil usaha kecil dibutuhkan oleh masyarakat banyak, dalam arti mempunyai pasar yang cukup luas (Sya'roni \& Sudirham, $2012: 45$ ).

Dengan adanya UMKM sumber daya lokal, pekerja lokal, dan pembiayaan lokal dapat terserap dan bermanfaat secara optimal. Berdasarkan data biro pusat statistik, sektor UMKM yang 
memiliki proporsi unit usaha terbesar tahun 2014-2015 adalah sektor (1) pertanian, peternakan, kehutanan dan perikanan; (2) perdagangan, hotel dan restoran; (3) industri pengolahan; (4) pengangkutan dan komunikasi; serta (5) jasa. Banyak UMKM yang memproduksi produk khas lokal (Ummi \& Ismail, 2017). Penelitian bertujuan untuk membuktikan pengaruh dimensi kreativitas terhadap pengembangan UMKM.

Kemampuan skill wirausaha yang modern, yang lebih memiliki wawasan, berpikiran jauh ke depan, senantiasa mengikuti perkembangan, terbuka terhadap konsep dan ide baru. Dengan pandangan yang jauh ke depan, selalu berkarya dan berkarsa, menciptakan sesuatu yang baru, terbuka terhadap pengalaman yang baru, termasuk tidak puas dengan apa yang dilakukan saat ini merupakan sisi keberhasilan dalam menjalankan aktivitas bisnisnya tersebut yang terkait dengan kompetensinya. Namun, demikian aplikasi dari hal-hal itu ternyata masih menjadi kendala pengusaha meraih keberhasilan dalam berusaha. Salah satu penentu keberhasilan tersebut adalah skill kewirausahaan yang dalam UMKM untuk mencapai keberhasilan tertentu di antaranya dipengaruhi oleh faktor kewirausahaan. Implikasi dari penerapan konsep kewirausahaan itu sendiri dalam organisasi bisnis dinyatakan bahwa apabila pengusaha ingin berhasil dalam menghadapi persaingan yang terbuka dalam era global saat ini harus memiliki jiwa kewirausahaan yang kreatif dan inovatif, terlebih melihat kondisi saat ini tentu diperlukan hal ini kreativitas maupun inovasi sebagai penentu yang merupakan ciri wirausaha (Sya'roni \& Sudirham, 2012 : 47). Pengembangan UMKM dipengaruhi oleh skill pelaku UMKM, pengembangan menuju kepada produk baru dan manajemen baru sehinga akan mempunyai daya saing yang tinggi dan tidak ditinggalkan oleh konsumen.

Mengkaji pengembangan skill UMKM sangat tergantung pada tingkat keahlian setiap individu dalam menjalankan pekerjaan dengan baik, langkah ini tidak semata-mata merupakan langkah yang harus diambil oleh Pemerintah dan hanya menjadi tanggung jawab Pemerintah. Pihak UMKM sendiri sebagai pihak internal yang dikembangkan, dapat mengayunkan langkah bersama-sama dengan Pemerintah. Karena potensi yang mereka miliki mampu menciptakan kreatifitas usaha dengan memanfaatkan fasilitas yang diberikan oleh pemerintah. Di Tegalalang, Gianyar-Bali banyak berkembang industri handycraft dengan jenis variasi dan skala usaha yang beragam, sehingga Tegalalang merupakan tempat tumbuhnya berbagai macam bentuk industri yang salah satunya usaha "handycraft" yang ada di Kabupaten Gianyar yang letaknya di Desa Tegalalang, Kecamatan Tegalalang, Kabupaten Gianyar-Bali. Berdasarkan data dari Dinas Koperasi dan UKM Kabupaten Gianyar terdaftar jumlah pengusaha "handycraft" sebanyak 44 unit. Industri ini mengolah bahan baku berbahan kayu albasia. Jenis usaha inilah yang menjadi produk unggulan Kabupaten Gianyar. Usaha "handycraft" berbahan kayu albasia ini sangat berpotensi untuk meningkatkan perekonomian masyarakat setempat karena pada dasarnya kayu albasia merupakan komoditi hasil perkebunan warga masyarakat Tegalalang yang sangat mudah untuk dibudidayakan sepanjang musim, baik di musim penghujan maupun di musim kemarau yang terpenting kebutuhan air tercukupi.

Ada beberapa kendala yang dihadapi oleh UMKM "handycraft" berbahan kayu albasia dalam pengembangan usahanya. Hal inilah yang menjadi pertimbangan peneliti untuk melakukan penelitian ini. Permasalahan yang paling mendasar dihadapi oleh pelaku UMKM ini meliputi, sumber daya manusia yang kurang memiliki ilmu pengetahuan dan keterampilan dalam pengembangan usahanya, memiliki permasalahan kurangnya sarana dan prasarana penunjang produksi, serta kurangnya akses pemasaran produk dan kerjasama kemitraan dengan pihak terkait.

Beberapa permasalahan di atas, memerlukan perhatian yang lebih dari pemerintah daerah Kabupaten Gianyar khusunya Dinas Koperasi dan UKM Kabupaten Gianyar, agar UMKM dapat tumbuh dan berkembang dengan lebih baik. Keberadaan UMKM ini perlu untuk dikembangkan karena pengembangan ini akan berpengaruh penting terhadap peningkatan perekonomian masyarakat untukmencapai kesejahteraan. Penelitian ini bertujuan untuk mengetahui, mendeskripsikan dan menganalisis peningkatan skill berwirausaha UMKM Tunjung Segara melalui penerapan model Paticipatory Rural Appraisal (PRA).

\section{Metode}

Jenis penelitian Tindakan (action research) atau disingkat dengan AR yaitu suatu proses demokratis dan partisipatorik yang menyangkut pengembangan pengetahuan praktis yang bermanfaat demi kemaslahatan kehidupan di dunia (Yaumi dan Damopolii, 2014 : 3-4). Subjek penelitian adalah para pekerja di UMKM Tunjung Segara yang berjumlah 20 orang. Data kuantitatif dikumpulkan berupa angket, dan analisis dokumen dengan menggunakan analisis deskriptif kuantitatif. Penelitian ini adalah merupakan suatu studi tentang hubungan antara variable skill dengan dalam pengembangan UMKM. 
Penelitian Tindakan (action research) dengan model pendekatan Paticipatory Rural Appraisal (PRA). Model PRA digunakan sebagai pendekatan pemecahan masalah UMKM. Menurut Muhsin, Nafisah, Siswanti (2018), PRA merupakan suatu model pendekatan dalam proses pemberdayaan masyarakat yang tekanannya pada keterlibatan masyarakat dalam keseluruhan kegiatan pembangunan. Model jenis ini dipilih karena pelaksanaan relatif mudah dilaksanakan, ekonomis dari segi waktu, serta banyak variabel yang dapat diekplorasi dan dipelajari korelasi atau pengaruhnya. Populasi penelitian adalah pekerja di UMKM Tunjung Segara yang berjumlah 20 orang pekerja, sampel menggunakan sampel jenuh yaitu menggunakan seluruh populasi menjadi sampel. Variabel penelitian ini terdiri dari variabel bebas dan terikat, yang dapat disebutkan sebagai berikut:

1. Variabel bebas: (a) skill;

2. Variabel terikat:; (b) pengembangan UMKM;

Langkah-langkah yang dilakukan dalam penelitian ini, secara umum melalui tahap-tahap:

1. Tahap persiapan. Pada tahap ini dilakukan pengamatan dan pengenalan subyek di dalam ruang kerja yang meliputi:

a) Pengamatan /observasi awal UMKM.

b) Penentuan sampel.

c) Sistem kerja UMKM target.

2. Tahap pengumpulan data: Metode pengumpulan data dalam penelitian ini dengan pengukuran langsung,

a) Pengukuran dimensi skill;

b) Pengukuran pengembangan UMKM.

Data yang diperoleh di analisis secara diskriptif kuantitatif. Hubungan antara variabel bebas dan terikat dianalisis secara analitik dengan menggunakan analisis korelasi dan regresi.. Analisis analitik memberikan penjelasan tentang hubungan antara variabel dimensi skill dalam pengembangan UMKM.

\section{Hasil dan pembahasan}

\section{Hasil Analisis}

\section{Pengujian Uji Asumsi Klasik}

Menurut Sarjono \& Julianita (2011 : 87) uji normalitas bertujuan untuk mengetahui normal atau tidaknya suatu distribusi data.

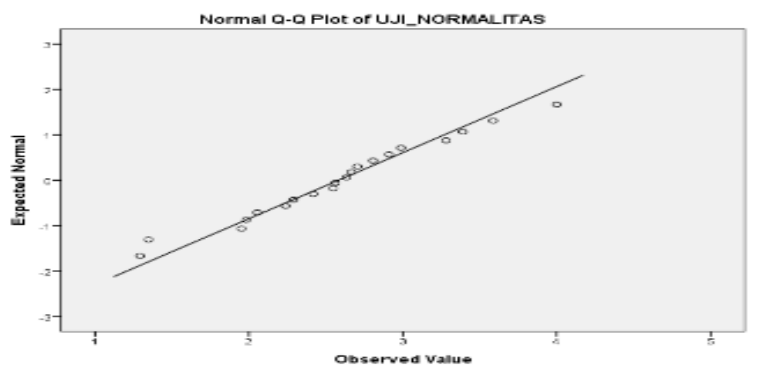

Gambar 1. Hasil Uji Normalitas Menggunakan P-Plot

Uji Multikolineritas adalah keadaan dimana pada model regresi ditemukan adanya korelasi yang sempurna atau mendekati sempurna antar variabel independen. Beberapa metode uji multikolinearitas yaitu salah satunya dengan melihat nilai Tolerance atau Variance Inflating Factor (VIF) pada model regresi.

Tabel 1. Uji Multikolineritas

\begin{tabular}{lllc}
\hline \multicolumn{1}{c}{ Model } & \multicolumn{2}{c}{ Collinearity Statistics } \\
& & Tolerance & VIF \\
\hline 1. Skill & 1,000 & & 1,000 \\
Kewirausahaan $(\mathrm{X})$ & & & \\
\hline
\end{tabular}

Uji heterokesdastisitas bertujuan untuk menguji apakah dalam model regresi terjadi ketidaksamaan variance dari residual pada satu pengamatan ke pengamatan yang lain. 


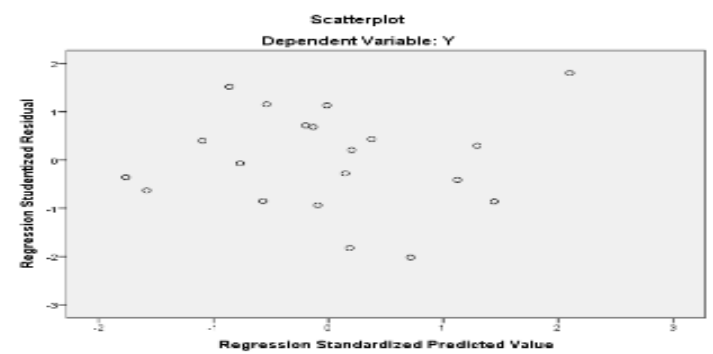

Gambar 2. Hasil Uji Heterokedatisitas

Uji Regresi Linier Sederhana nilai konstanta dan koefisien regresi sehingga dapat dibentuk persamaan regresi linier sederhana sebag

Berdasarkan hasil pengolahan data didapat ai berikut:

$\mathrm{Y}=80.62+66.43 \mathrm{X}$

$\alpha=86,01$

Ini menunjukkan bahwa variabel skill kewirausahaan (X) berpengaruh secara positif terhadap pengembangan UMKM (Y) dengan penerapan model Paticipatory Rural Appraisal (PRA) jika variabel skill kewirausahaan ditingkatkan sebesar satu satuan, maka kinerja usaha akan meningkat sebesar 66.43.

Tabel 2. Hasil Uji t Pengaruh skill Pekerja terhadap pengembangan UMKM

\begin{tabular}{|c|c|c|c|c|c|c|c|}
\hline \multirow{2}{*}{\multicolumn{2}{|c|}{ Model }} & \multicolumn{2}{|c|}{$\begin{array}{c}\text { Unstandardized } \\
\text { Coefficients }\end{array}$} & \multirow{2}{*}{$\begin{array}{c}\text { Standardized } \\
\text { Coefficients } \\
\text { Beta }\end{array}$} & \multirow[b]{2}{*}{$\mathrm{T}$} & & \multirow[b]{2}{*}{ Sig } \\
\hline & & $\mathrm{B}$ & Std. Error & & & & \\
\hline & (Constant) & 80.62 & 80.278 & & 971 & .931 & \\
\hline & Skill Pekerja & 66.43 & 67.614 & .935 & 10.733 & .000 & \\
\hline
\end{tabular}

a. Dependent Variable: Pengembangan Usaha (Y)

Sumber: Hasil Olah Data Peneliti Menggunakan SPSS 22

Tabel dibuat dengan lebar garis 1 pt dan tables caption (keterangan tabel) diletakkan di atas tabel. Keterangan tabel yang terdiri lebih dari 2 baris ditulis menggunakan spasi 1. Garis-garis tabel diutamakan garis horizontal saja sedangkan garis vertikal dihilangkan.

Uji Hipotesis (Uji T)

Hasil pengujian hipotesis parsial (uji t) pada variabel skill kewirausahaan (X):

Ho: skill kewirausahaan tidak berpengaruh terhadap pengembangan UMKM

Ha: skill kewirausahaan berpengaruh terhadap pengembangan UMKM

Variabel skill kewirausahaan (X) memiliki nilai t hitung lebih besar dari nilai t tabel karena nilai $\mathrm{t}$ hitung $(5,387)>t$ tabel $(0,444)$ dan tingkat signifikansi $, 000<0,05$, maka Ho ditolak dan Ha diterima. Maka dapat disimpulkan bahwa terdapat pengaruh dari variabel skill kewirausahaan (X) terhadap pengembangan UMKM (Y) dengan penerapan model Paticipatory Rural Appraisal (PRA). Hasil perhitungan pengujian parsial dapat dilihat pada tabel berikut:

Tabel 3. Hasil Uji t Pengaruh Skill Pekerja terhadap Pengembangan UMKM

\begin{tabular}{|c|c|c|c|c|c|c|c|}
\hline \multirow{2}{*}{\multicolumn{2}{|c|}{ Model }} & \multicolumn{2}{|c|}{$\begin{array}{l}\text { Unstandardized } \\
\text { Coefficients }\end{array}$} & \multirow{2}{*}{ 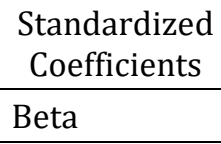 } & \multirow[b]{2}{*}{$\mathrm{T}$} & & \multirow[b]{2}{*}{ Sig. } \\
\hline & & $\mathrm{B}$ & Std. Error & & & & \\
\hline & (Constant) & 8.019 & 9.329 & & .844 & .403 & \\
\hline & Skill Pekerja & .779 & .077 & .608 & 10.072 & .000 & \\
\hline
\end{tabular}

b. Dependent Variable: Kinerja Usaha (Y)

Sumber: Hasil Olah Data Peneliti Menggunakan SPSS 22 
Koefisien Determinasi (R2) Koefisien determinasi (R2) digunakan untuk melihat seberapa besar kontribusi variabel bebas $(\mathrm{X})$ yaitu skill kewirausahan terhadap variabel terikat (Y) yaitu pengembangan UMKM. Berdasarkan hasil analisis koefisien determinasi didapatkan hasil bahwa besarnya pengaruh variabel skill kewirausahaan (X) terhadap variabel pengembangan UMKM $(\mathrm{Y})$ adalah sebesar 73,9\%. Sedangkan sisanya sebesar 36,3\% dipengaruhi oleh faktor lain seperti SDM, motivasi, dan pendampingan. Hasil penelitian menunjukan bahwa skill kewirausahaan berpengaruh signifikan terhadap pengembangan UMKM. Hasil penelitian ini sejalan dengan penelitian yang dilakukan oleh Utami \& Mulyaningsih (2016), membuktikan bahwa kompetensi kewirausahaan berpengaruh signifikan terhadap peningkatan kinerja UMKM di Malang. Penelitian yang dilakukan Darya (2012), yang membuktikan kompetensi kewirausahaan berpengaruh positif dan signifikan terhadap kinerja UMKM di Balikpapan. Demikian pula penelitian yang dilakukan oleh Putri (2020) yang membuktikan bahwa keunggulan bersaing berpengaruh terhadap kinerja UMKM di Kabupaten Rokan Hilir.

\section{Simpulan dan Saran}

\section{a. Simpulan}

Berdasarkan hasil pengumpulan dan pengolahan data, pengujian hipotesis serta pembahasan hasil penelitian, maka kesimpulan dari penelitian ini adalah sebagai berikut;

1. Skill Kewirausahaan Pada UMKM Tunjung Segara dengan penerapan model Paticipatory Rural Appraisal (PRA) berbasis skill pada pengembangan keterampilan kewirausahaan, berdasarkan hasil penelitian dan analisis deskriptif, variabel skill kewirausahaan (X) secara keseluruhan masuk dalam kategori "baik". Pada variabel skill kewirausahaan yang mendapat nilai tertinggi adalah pernyataan tentang "dalam menjalankan usaha, pekerja di UMKM Tunjung Segara mampu memahami lingkungan usaha yang ditekuni" dengan persentase sebesar $66.43 \%$ dan masuk dalam kategori "baik". Hal ini menunjukan bahwa UMKM dengan penerapan model Paticipatory Rural Appraisal (PRA) berbasis skill pada pengembangan keterampilan kewirausahaan dapat memahami lingkungan usaha yang dimiliki. Pernyataan yang mendapat nilai terendah masuk dalam kategori "cukup" yaitu pernyataan mengenai "dalam menjalankan usaha, pekerja di UMKM Tunjung Segara selalu mencari peluang-peluang baru dalam mengembangkan" dengan persentase sebesar 60.8\%. Hal ini menunjukan bahwa UMKM belum dapat mencari peluang usaha baru dengan baik.

2. Skill UMKM Tunjung Segara penerapan model Paticipatory Rural Appraisal (PRA) berbasis kinerja pada pengembangan keterampilan kewirausahaan, berdasarkan hasil penelitian dan analisis deskriptif, variabel skill usaha $(\mathrm{Y})$ menurut tanggapan responden secara keseluruhan masuk ke dalam kategori "Baik". Pada variabel skill usaha yang mendapat nilai tertinggi adalah pernyataan tentang "Meningkatnya pendapatan rata -rata UMKM setelah adanya pendampingan" dengan persentase sebesar 66.43 \% dan masuk dalam kategori "baik". Hal ini menunjukan bahwa UMKM dengan penerapan model Paticipatory Rural Appraisal (PRA) berbasis kinerja pada pengembangan skill kewirausahaan mengalami kenaikan pendapatan setelah didampingi. Pernyataan yang mendapat nilai terendah masuk dalam kategori "cukup" yaitu pernyataan mengenai "UMKM mengetahui tata cara mendapatkan bantuan dana modal usaha" dengan persentase sebesar $60.8 \%$. Hal ini menunjukan bahwa kurangnya pengetahuan UMKM tentang cara mendapatkan mengembangkan pemasaran online usaha.

3. Pengaruh skill Kewirausahaan Terhadap Kinerja Usaha Kompetensi Kewirausahaan berpengaruh terhadap pengembangan usaha UMKM dengan penerapan model Paticipatory Rural Appraisal (PRA) berbasis kinerja pada pengembangan keterampilan kewirausahaan, berdasarkan hasil perhitungan koefisien determinasi (R2) dapat diketahui besarnya pengaruh variabel skill kewirausahaan $(\mathrm{X})$ terhadap kinerja usaha $(\mathrm{Y})$ adalah sebesar 73,9\%. Sedangkan sisanya sebesar $36,3 \%$ dipengaruhi oleh faktor lain seperti SDM, motivasi, dan pendampingan.

\section{b. Saran}

Menjadikan model Paticipatory Rural Appraisal (PRA) berbasis kinerja dalam menunjang peningkatan skill berwirausaha UMKM Tunjung Segara sebagai agenda yang dilakukan secara sustainable dan dilakukan untuk UMKM diseluruh Indonesia agar UMKM di Indonesia dapat meningkatkan tingkat pendapatannya. Melakukan penyuluhan rutin bagi UMKM yang telah menerapkan model Paticipatory Rural Appraisal (PRA) agar UMKM dapat termotivasi dan terus mengembangkan usahanya. Menambahkan jumlah UMKM yang dilibatkan dengan model Paticipatory Rural Appraisal (PRA) agar semakin banyak UMKM yang dapat mengembangkan skill kewirausahaannya. UMKM dapat mencari peluang-peluang baru dalam mengembangkan usaha yang dijalankan agar dapat meningkatkan pendapatan. UMKM harus mampu menjalankan usaha sampai 
berhasil. UMKM dapat dengan skill berwirausaha, UMKM yakin dalam mengambil keputusan untuk menjalankan usaha yang baru agar dapat meningkatkan penghasilan.

\section{Daftar Rujukan}

Anggraeni, F. D. (2013). Pengembangan Usaha Mikro, Kecil dan Menengah (UMKM) Melalui Fasilitasi Pihak Eksternal dan Potensi Internal (Studi Kasus Pada Kelompok Usaha" Emping Jagung" di Kelurahan Pandanwangi Kecamatan Blimbing Kota Malang). Jurnal Administrasi Publik, 1(6), 12861295.

Christiana, Y., Pradhanawati, A., \& Hidayat, W. (2014). Pengaruh Kompetensi Wirausaha, Pembinaan Usaha dan Inovasi Produk Terhadap Perkembangan Usaha (Studi Pada Usaha Kecil dan Menengah Batik di Sentra Pesindon Kota Pekalongan). Jurnal Ilmu Administrasi Bisnis, 3(4), 384-393.

Darya, I Gusti Putu. 2012. Pengaruh Ketidakpastian Lingkungan dan Karakteristik Kewirausahaan terhadap Kompetensi Usaha dan Kinerja Usaha Mikro Kecil di Kota Balikpapan. Jurnal Inovasi dan Kewirausahaan: Vol. 1. No.1. hal. 65-78.

Heliantina, Farah. (2017). Siaran Pers-Ekonomi Digital Mempercepat Pembangunan Ekonomi. Kementerian Koordinator Bidang Perekonomian Republik Indonesia. Tersedia di www.ekon.go.id

Hendrawan, A., Kuswantoro, F., \& Sucahyawati, H. (2019). Dimensi Kreativitas dan Pengembangan Usaha Mikro Kecil dan Menengah (UMKM). Jurnal HUMMANSI (Humaniora, Manajemen, Akuntansi), 2(1).

Nafisah, L., \& Siswanti, Y. (2018). Participatory Rural Appraisal (PRA) for Corporate Social Responsibility (CSR). no. I. Yogyakarta: Deepublish.

Putri, S. M. (2020). Pengaruh Keunggulan Bersaing dan Kompetensi KewirausahaanTerhadap Kinerja Usaha Mikro, Kecil, dan Menengah (UMKM)(Studi Empiris pada UMKM di Kabupaten Rokan Hilir). Journal of Public and Business Accounting, 1(2), 43-53.

Sarjono, H., \& Julianita, W. (2011). SPSS vs LISREL: Sebuah Pengantar, Aplikasi untuk Riset. Jakarta: Salemba Empat.

Sri, M., \& Ahmad, Y. (2017). Peluang dan Tantangan Pengembangan Usaha Mikro Kecil Menengah (UMKM) Dari Berbagai Aspek Ekonomi. Jurnal Ilmiah Manajemen Dan Bisnis, 2(1), 181-197.

Sutipyo. (2014). Kreativitas, pemacu dan penghambatnya dalam kehidupan manusia. Al-Misbah, 203-218.

Sya'roni, D., \& Sudirham, J. (2012). Kreativitas dan inovasi Penentu Kompetensi Pelaku Usaha Kecil . Jurnal Manajemen Teknologi, 42-59.

Ummi, N., \& Ismail, T. (2017). Strategi Pengembangan Klaster Bisnis UKM Banten Berbasis Kekhasan Lokal Dengan Pendekatan Diamond Cluster, Analisis SWOT dan Analytical Hierarchy Process. Conference on Management and Behavioral Studie, (pp. 118-127).

Utami, E. N., \& Mulyaningsih, H. D. (2016). Pengaruh kompetensi kewirausahaan terhadap kinerja UMKM. Bisnis Dan Iptek, 9(2), 98-109.

Yaumi, Muhammad dan Muljono Damopolli. 2014. Action Research: Teori, Model dan Aplikasi. Edisi Pertama. Kencana Prena Grafika Group. Jakarta. 